\section{Sir Thomas Hudson Beare}

Thomas Hudson Beare was born at Adelaide, South Australia, on June 30, 1859, and was educated at Prince Alfred College and the University of Adelaide. After obtaining the B.A. degree he was awarded the Fife (Australia) scholarship, and he then proceeded to London, where he studied at University College and obtained the B.Sc. degree of the University of London.

Before leaving Australia, Hudson Beare held an appointment in the Public Works Department, and was engaged on railway construction, and after completion of the London degree he had further practical experience in the Midlands and in Manchester.

In 1884 he was invited to join the staff at University College, London, and for three years assisted Prof. A. B. W. Kennedy in teaching and in private professional work. In a testimonial written in his favour at the end of that period, Prof. Kennedy commented on his ability as a teacher and an organizer, on his knowledge and skill as an engineer. Shortly afterwards, Hudson Beare was appointed to the chair of mechanics and engineering in the Heriot-Watt College, Edinburgh. He was the first occupant of this chair, and in two years he built up a most successful department.

In 1889 , on the resignation of Prof. Kennedy, he was appointed to the chair of engineering at University College, London, and was very largely responsible for the planning and equipment of the new Engineering Department which was built in 1895. During this period, in addition to his normal duties, he was able to carry out a considerable amount of research work, and was awarded the Telford Premium by the Institution of Civil Engineers for a valuable paper on "The Building Stones of Great Britain". As a member of the Research Committees on Steam Jackets and on Marine Engine Trials, he published several papers in the Proceedings of the Institution of Mechanical Engineers.

In 1901 Hudson Beare was appointed regius professor of engineering at the University of Edinburgh. The Engineering Department of that time was small, poorly equipped and very inadequately housed, but under Hudson Beare's energizing influence the number of students rapidly increased, and in 1905 the Department was accommodated in new and well-equipped premises. So successful was he that the Edinburgh school attracted students from all parts of the Empire, from the Continent, from China and South America, and it was again found that the accommodation was inadequate. Once more Sir Thomas undertook the design of new laboratories, and in 1931 the Department was transferred to the Sanderson Engineering Laboratories at King's Buildings.

In 1913 Sir Thomas was elected dean of the Faculty of Science at Edinburgh, a post which he held until his death on June 10 last, and his expert knowledge and great administrative ability enabled him to render invaluable service to the University. For many years he was convener of the Works Committee of the University Court, and carried the enormous responsibility of supervising the erection of many new departments and of the many alterations required to adapt the older buildings to modern requirements. In 1908 he was appointed convener of the Military Education Committee of the University, and his keen interest in military affairs was largely instrumental in raising the Edinburgh University contingent of the Officers Training Corps to its high state of efficiency. He also represented the University as a member of the City of Edinburgh Territorial and Air Force Association, and for a period acted as chairman.

Sir Thomas acted for several terms as vice-president of the Royal Society of Edinburgh, was vice-president of the Board of Governors of the Edinburgh and East of Scotland College of Agriculture from 1932, chairman of the Board of Governors of the Royal (Dick) Veterinary College from 1923, and for many years a governor of the Heriot-Watt College. In 1921 he was appointed by the Secretary of State for Scotland as an assessor on the Central Miners' Welfare Committee, and served on the Commission until the time of his death. His knighthood was conferred upon him in 1926, and ten years later he received the honorary degree of LL.D. from the University of Edinburgh. He was a member of the Institution of Civil Engineers, a member and later an honorary life member of the Institution of Mechanical Engineers, and a member and vice-president of the Institution of Structural Engineers. He was a justice of the peace and Deputy Lieutenant of the County of the City of Edinburgh.

A man of outstanding ability, Sir Thomas's interest lay not in himself but in the work which came to his hands. In the later period of his service his many administrative duties compelled him, of necessity, to give up research work but never prevented him from keeping closely in touch with the latest developments in engineering. Throughout all the years he was able to continue his clear and logical teaching in his own department. Keenly interested as he was in students and in all their activities, it is not surprising that he won their regard and confidence, and this was reflected in the close associations they maintained with him in after-life. He was not merely a teacher of engineering and a great figure in the profession to which they belonged, but also one who inspired them with a sense of conscientiousness, of honour and of integrity in the carrying out of the duties of life. During these almost incredibly busy years relaxation was found in travel and in the study of Nature, but even in recreation his alertness of mind asserted itself, and he was accepted by entomologists as an authoritative specialist on the systematics of the Coleoptera. J. B. ToDD.

\section{Dr. Matthew Young}

WE regret to record the death of Dr. Matthew Young, anatomist and anthropologist, which took place on May 25 at the age of fifty-six.

Matthew Young was born in Ayrshire and educated at Kilmarnock Academy and the University of

(Continued on page 1011) 